\title{
ANALISIS MAKANAN PRA-PERTANDINGAN YANG TEPAT UNTUK ATLET
}

\author{
Mudrikah Khilda Noor \\ S1 Pendidikan Dokter Fakultas Kedokteran Universitas Lambung Mangkurat \\ Mudrikah.helda@gmail.com
}

\begin{abstract}
ABSTRAK
Atlet dapat memperoleh stamina yang baik dengan mengonsumsi gizi yang memenuhi kebutuhan mereka untuk bertanding. Tidak jarang para atlet diliputi kecemasan saat mengikuti kompetisi. Kecemasan yang ditimbulkan terkadang berlebihan sehingga mempengaruhi kondisi fisik dan psikis atlet salah satunya nafsu makan. Menilik dari beragamnya kondisi atlet tersebut maka dilakukanlah penelitian ini untuk menganalisis makanan pra-pertandingan yang tepat untuk atlet sehingga dapat menunjang performa atlet dalam pertandingan. Metode yang digunakan adalah metode kajian literatur dengan mengambil beberapa sumber yang terdiri dari artikel, buku elektronik, jurnal, dan makalah. Kesimpulan yang diperoleh yaitu sebelum tanding atlet dianjurkan makan menu ringan, tinggi karbohidrat terutama dengan indeks glikemik rendah, cukup protein, rendah lemak, tidak bergas dan mudah cerna.
\end{abstract}

Kata Kunci: Atlet, Pra-Pertandingan, Makanan, kecemasan

\section{PENDAHULUAN}

Penampilan atlet pada suatu pertandingan ditentukan oleh beberapa komponen yaitu fisik, teknik, taktik, dan psikis (Effendi, 2017). Tidak jarang para atlet diliputi kecemasan saat mengikuti kompetisi. Kecemasan yang ditimbulkan terkadang berlebihan sehingga mempengaruhi kondisi fisik dan psikis atlet (Effendi, 2017). Agustianto (2012) mengungkapkan bahwa kecemasan sering kali mempengaruhi kehidupan sehari-hari dan mengganggu sistem pencernaan, seperti kehilangan nafsu makan. Sejalan dengan yang diungkapkan oleh Almatsier, (2011), bahwa orang yang mengalami kecemasan akan mengalami perubahan selera makan menjadi selera makan yang meningkat atau justru menurun. Hal ini tentu akan mempengaruhi performa dan prestasi atlet yang akan bertanding jika ia mengalami kecemasan berlebih dan mempengaruhi sistem pencernaannya. Sedangkan seorang atlet memerlukan gizi dan nutrisi untuk menunjang stamina dalam pertandingan.

Atlet dapat memperoleh stamina yang baik dengan mengonsumsi gizi yang 
memenuhi kebutuhan mereka selama latihan dan pertandingan (Subakti, 2010) Dari perspektif fisiologi olahraga. Atlet berpartisipasi dalam berbagai cabang dan nomor olahraga. Keseluruhan ini juga akan menghasilkan adaptasi yang berbeda untuk setiap individunya.

Klasifikasi menurut energi utama yang digunakan dalam berolahraga melalui mekanisme pembentukan energi di dalam tubuh dari energi kimia menjadi energi mekanik, maka dapat dibagi menjadi olahraga aerobik dan olahraga anaerobik yang kemudian tersebar menjadi bermacam cabang olahraga beserta nomornya. Olahraga anaerobik sering dihubungkan dengan aktivitas latihan yang singkat, repetisi dan intensitas yang tinggi (Deswandi, 2012). Sumber energi olahraga anaerobik menggunakan sumber energi di otot yang dibakar tanpa oksigen dari udara. Contoh olahraga anaerobik yaitu lari jarak pendek, lompat jauh, lompat tinggi, angkat beban, karate, judo, gulat dan lainnya (Nugroho, 2013). Sedangkan olahraga aerobik menurut Sherwood (2018) melibatkan kelompok-kelompok otot besar dan dilakukan dengan intensitas yang cukup rendah serta dalam waktu yang cukup lama, sehingga sumber-sumber bahan bakar dapat diubah menjadi ATP dengan menggunakan siklus asam sitrat.
Contoh olahraga aerobic yaitu marathon, renang, sepeda, dan lainnya.

Aktivitas olahraga pada umumnya tidak hanya menggunakan salah satu sistem aerobik atau anaerobik saja, namun sebenarnya yang terjadi adalah menggunakan gabungan kedua sistem aerobik dan anaerobik, akan tetapi porsi kedua sistem tersebut berbeda pada setiap cabang olahraga. Cabang olahraga yang telah disebutkan diatas merupakan pengelompokkan sistem energi predominannya antara aerobik dan anaerobik, sedangkan olahraga yang menggunakan sistem energi aerobik dan anaerobic yaitu lari jarak menengah (800$3000 \mathrm{~m}$ ), bulutangkis, tenis, bola basket, sepakbola, dan sebagainya (Sucipto, 2012).

Menilik dari beragamnya kondisi atlet tersebut maka dilakukanlah penelitian ini untuk menganalisis makanan prapertandingan yang tepat untuk atlet sehingga dapat menunjang performa atlet dalam pertandingan. Makanan yang tepat akan menghasilkan kondisi fisik yang baik, karena makanan yang dikonsumsi itu akan memenuhi kebutuhan yang sesuai dengan tubuh atlet (Subakti, 2010).

\section{METODE PENELITIAN}

Pada penulisan ini, metode yang digunakan adalah metode kajian literatur. Dengan sumber literatur terdiri atas artikel, 
jurnal, buku elektornik, dan makalah skripsi. Teknik pengumpulan data dilakukan secara digital. Setelah mengumpulkan data dari berbagai sumber literatur, selanjutnya data dikembangkan sampai didapatkan hasil dan tercapainya tujuan dari pembuatan artikel ini.

\section{HASIL DAN PEMBAHASAN}

Selain pemakaian karbohidrat pada jumlah besar selama kerja fisik, terutama selama tahap awal kerja fisik, otot memakai sejumlah besar lemak menjadi tenaga dalam bentuk asam lemak \& asam asetoasetat, dan otot memakai dalam jumlah yang lebih sedikit protein yaitu dalam bentuk asam amino (Guyton \& Hall, 2014).

Dikemukakan Guyton \& Hall (2014), bahwa sebagian besar energi diperoleh dan karhohidrat selama beberapa detik atau menit pertama kerja fisik, tetapi saat timbul kelelahan, sebanyak 60 sampai 85 persen energi diperoleh dari lemak, bukan dari karbohidrat. Sumber energi yang paling cepat tersedia untuk kontraksi otot adalah Adenosine Triphospate (ATP) (Hairy, 2003). Saat beraktifitas, ATP akan diubah menjadi Adenosine diphosphate (ADP) dan phosphate inorganic (Pi), dan dihasilkanlah energi yang dapat mengkontraksi otot (Rismayanthi, 2015).
Energi yang diperlukan agar otot dapat berkontraksi ini dapat diperoleh melalui dua cara yaitu secara anaerobik atau tidak menggunakan oksigen dan secara aerobik atau menggunakan oksigen (Sandi, 2019). Untuk aerobik sendiri terdiri dari dua sistem, antara lain sistem ATP-CP dan sistem asam laktat. Sistem ATP-CP (Adenosin Triphosphate - creatine phosphate) sendiri merupakan cara memperoleh energi seperti yang telah dijelaskan sebelumnya, yaitu ATP yang diuraikan menjadi ADP dan Pi, menghasilkan energi yang digunakan untuk kontraksi otot skelet (Rismayanthi, 2015). Creatine Phosphate (CP) atau fosfokreatin adalah fosfat berenergi tinggi yang tidak dapat secara langsung digunakan dalam kerja otot, akan tetapi digunakan untuk memperbaharui atau membentuk ATP dari ADP. fosfokreatin yang di dalam otot pun jumlahnya sangat terbatas sehingga hanya dapat berlangsung dalam waktu singkat (Sandi, 2019). Jadi, Sistem ATP-CP bekerja pada cabang olahraga dengan intensitas dan kecepatan yang tinggi seperti lari sprint $<100$ meter, lompat, angkat besi, dan menyelam (diving) (Bompa \& Haff, 2009)

Sistem asam laktat disebut juga sistem glikolisis. Glikolisis sendiri diartikan oleh Sherwood (2018) yaitu proses biokimiawi yang berlangsung di 
sitosol sel yang menguraikan glukosa menjadi asam piruvat dalam sistem aerob dan menjadi asam laktat dalam sistem anaerob. Glukosa yang diuraikan yaitu glukosa dari glikogen otot. Sistem asam laktat penting untuk olahraga dengan intensitas tinggi dengan lama waktu sekitar 20 detik - 2 menit seperti lari sprint 200 $800 \mathrm{~m}$, renang gaya bebas $100 \mathrm{~m}$ (Rismayanthi, 2015). Cabang olahraga lain yang juga dominan menggunakan sistem asam laktat atau sistem glikolisis ini adalah bersepeda jarak 1.000 meter, dan kano jarak 500 meter (Bompa \& Haff, 2009). Sistem glikolisis sangat penting kiprahnya dalam olahraga, hal ini disebabkan lantaran keuntungan yang diperoleh yaitu dengan menyediakan sumber energi yang begitu banyak tanpa membutuhkan oksigen. Namun, disamping keuntungan tersebut sistem ini juga tak lepas dari kelemahan yaitu menghasilkan asam (Sandi, 2019). Seperti yang dikatakan oleh Pate, et al (1993) bahwa jika terdapat penumpukan asam laktat di dalam otot, maka akan menyebabkan fungsi otot tersebut melemah dan menimbulkan kelelahan.

Sistem aerobik memerluksn oksigen untuk memecahkan glikogen/ glukosa menjadi $\mathrm{C} 02$ dan $\mathrm{H} 20$ melalui siklus krebs (Rismayanthi, 2015). Sistem aerobik bekerja menghasilkan ATP lebih lambat daripada sistem ATP-CP dan asam laktat, tetapi sistem aerobik memproduksi ATP jauh lebih besar. Sistem aerobik digunakan pada cabang olahraga yang membutuhkan energi lebih dari 3 menit seperti lari marathon, renang gaya bebas 1500 m. (Wolinsky \& Hickson Jr, 1993)

Makanan dapat dianggap sebagai bahan bakar mentah, sementara ATP adalah bahan bakar yang telah disuling untuk mengoperasikan perangkat sel (Linder \& Parakkasi, 1992). Pengaturan makanan pada atlet bertujuan untuk memperbaiki dan mempertahankan status gizi agar dalam keadaan stabil, tidak terjadi kurang gizi atau gizi berlebih (kegemukan), membentuk otot dan mencapai bentuk tubuh yang proporsional serta memelihara kondisi tubuh dan kesegaran jasmani (Primana, 2002). Makanan yang dikonsumsi sebelum pertandingan harus mengandung karbohidrat agar dapat meningkatkan dan mempertahankan kadar gula darah tanpa mengeluarkan insulin secara drastis (Syafrizar \& Welis, 2009). Manfaat terbesar dari makanan prapertandingan adalah mencegah lapar bagi atlet selagi bertanding (Sherwood, 2018). Menurut Syafrizar \& Welis (2009) ada beberapa petunjuk yang dapai digunakan dalam pengaturan makan atlet sebelum pertandingan, yaitu:

- 3 jam sebelum tanding atlet dianjurkan makan menu ringan, tinggi karbohidrat 
terutama dengan indeks glikemik rendah, cukup protein, rendah lemak, tidak bergas dan mudah cerna

- Diusahakan tidak memberikan makanan sumber glukosa 30 menit atau kurang sebelum pertandingan berlangsung. Hal ini akan menyebabkan hipoglikemia.

- Bagi atlet yang gugup dan cemas berikan makanan cair

- Untuk olahraga endurance/daya tahan dapat diberikan diet khusus (carbohidrat loading) beberapa hari (1 minggu) sebelum bertanding.

Jenis pilihan terbaik untuk makanan pra-pertandingan adalah makanan yang mengandung banyak karbohidrat serta rendah lemak dan protein. Tujuannya adalah untuk menjaga kadar gula darah dan penyimpanan karbohidrat dalam tubuh, serta mencegah makanan yang tidak tercerna menumpuk di lambung saat bertanding. Makanan tinggi karbohidrat dianjurkan karena lebih mudah dicerna dan dikosongkan daripada makanan yang mengandung lemak atau protein (Sherwood, 2018). Makanan berkarbohidrat tinggi juga membantu "mengisi ulang" penyimpanan glikogen otot dalam waktu 3-4 jam setelah makan (Chryssanthopoulos, et al., 2004) (Wee, et al., 2005). Sherman, et al (1989) menunjukkan bahwa meskipun sejumlah kecil karbohidrat (46 dan 156 g) dikonsumsi 4 jam sebelum bersepeda intermiten meningkatkan kapasitas daya tahan, jumlah yang lebih besar (312g) bahkan lebih efektif. Setelah jumlah karbohidrat yang lebih besar ini, kapasitas latihan menjadi 15\% lebih besar (56 menit) daripada setelah uji coba plasebo air (48 menit). Pilihan yang baik sebagai makanan pra-pertandingan antara lain adalah roti, pasta, nasi, kentang, gelatin, yogurt, dan jus buah (Sherwood, 2018). Pancake atau wafel juga sangat baik seperti sereal dengan susu rendah lemak. Orak-arik atau telur rebus juga baik jika pertandingan pertama tidak sampai tengah hari atau beberapa jam setelah sarapan (William, 2008).

Makanan pra-pertandingan adalah perihal yang sangat individual, dengan beberapa atlet yang dalam kondisi stres dan cemas membutuhkan suplemen makanan cair dalam jumlah kecil, dan yang lainnya bahkan tidak dapat mentolerir makanan apa pun (Holway \& Spriet, 2011). Jika makan makanan berkarbohidrat $3-4$ jam sebelum bertanding menyebabkan ketidaknyamanan gastrointestinal, salah satu alternatifnya adalah minum larutan karbohidrat. Strategi nutrisi ini bahkan memungkinkan atlet untuk mengonsumsi karbohidrat dengan efek yang baik selambat-lambatnya 1 jam sebelum berolahraga. Minum larutan karbohidrat-elektrolit juga tampaknya 
meningkatkan kapasitas daya tahan selama latihan intermiten bahkan ketika pemain memiliki simpanan glikogen otot pralatihan yang tinggi (Williams \& Serratosa, 2006).

Hindari makanan seperti muffin (kecuali yang rendah lemak), donat, sosis, bacon, dan kopi. Jangan menambahkan banyak mentega, krim keju, jeli atau sirup ke bagel, roti panggang, atau pancake yang akan dimakan (William, 2008). Makanan yang mengandung lemak khususnya menghambat pengosongan lambung dan tergolong lambat dicerna. Sedangkan makanan tinggi protein dalam metabolisme proteinnya akan menghasilkan zat sisa bernitrogen seperti urea yang aktivitas osmotiknya akan menarik air dari tubuh dan meningkatkan volume urine. Perlu juga menghindari makanan atau minuman dengan kandungan gula tinggi, karena memicu pelepasan insulin (Sherwood, 2018). Setelah seseoranq mulai berolahraga, sensitivitas terhadap insulin meningkat menyebabkan terjadinya shock insulin atau rebound yang mengakibatkan hipoglikemia (kadar gula rendah atau $<50$ mg \%), sehingga memicu rasa lelah dan meningkatkan pemakaian glikogen otot yang berpengaruh negatif terhadap kinerja atlet dalam berlatih maupun bertanding. konsumsi gula tepat sebelum kompetisi malah dapat menghambat kinerja bukannya memberi tambahan tenaga seperti yang diinginkan (Sherwood, 2018) (Syafrizar \& Welis, 2009)

$$
\text { Atlet harus menghindari }
$$
penggunaan kafein karena dapat mengganggu kinerja saat bertanding seperti denyut jantung berlebihan, memacu produksi urin dan bagi atlet yang sensitif dapat menyebabkan depresi yang membuat atlet gelisah serta menderita insomnia. Konsentrasi kafein yang tinggi dalam urin yaitu lebih dari $12 \mathrm{ug} / \mathrm{ml}$ dianggap doping atau setara minum 15 cangkir kopi dalam sehari, sudah dianggap doping (Syafrizar \& Welis, 2009).

Dalam satu jam pertandingan, atlet sebaiknya hanya minum air untuk memastikan hidrasi yang cukup (Sherwood, 2018). Porsi makanan prapertandingan tergantung pada waktu mulai pertandingan pertama. Jika waktu mulai pertandingan adalah tengah hari, antara pukul 9:30 dan 11:00, maka atlet harus makan lebih banyak, juga bisa ditambahkan sedikit lebih banyak protein, seperti telur dan sereal. Jika jadwal pertandingan tepat pada pagi hari sekitar pukul 8:00, maka atlet harus mengkonsumsi makanan kaya karbohidrat (William, 2008).

\section{KESIMPULAN}

Energi dapat diperoleh melalui dua cara yaitu secara anaerobik dan secara 
aerobik. aerobik terdiri dari dua sistem, yaitu sistem ATP-CP dan sistem asam laktat. Sistem ATP-CP bekerja pada cabang olahraga dengan intensitas dan kecepatan yang tinggi dan sistem asam laktat untuk olahraga dengan intensitas tinggi yang memakan waktu sekitar 20 detik - 2 menit. Sedangkan Sistem aerobik digunakan pada cabang olahraga yang membutuhkan energi lebih dari 3 menit. Jenis pilihan terbaik untuk makanan pra-pertandingan adalah makanan yang mengandung banyak karbohidrat terutama dengan indeks glikemik rendah, cukup protein dan rendah lemak. Alternatif pengganti makanan pada atlet dengan kondisi khusus seperti stress, cemas atau bahkan gangguan gastrointestinal dapat menggunakan minum larutan karbohidrat. Atlet harus menghindari makanan atau minuman dengan kandungan gula tinggi, karena memicu pelepasan insulin dan terjadi hipoglikemia. Sedangkan penggunaan kafein akan mengganggu performa atlet saat bertanding.

\section{SARAN}

Menjelang pertandingan, para pelatih harus benar-benar memperhatikan kondisi para atlet khususnya dalam hal makanan. Apa yang dimakan, berapa jumlah yang harus dimakan, kapan waktu yang tepat untuk makan harus selalu dalam pantauan agar atlet tidak mengalami lapar atau bahkan kekenyangan saat akan bertanding yang mana tentunya akan mengganggu performa atlet.

\section{DAFTAR PUSTAKA}

Agustianto, 2012. Psikologi untuk Keperawatan. Jakarta: EGC.

Almatsier, S., 2011. Kesehatan Masyarakat. Jakarta: EGC.

Bompa, T. O. \& Haff, G. G., 2009. Periodization : theory and methodology of training. $5 \mathrm{ed}$. United State: Leeds : Human Kinetics.

Chryssanthopoulos, C., Williams, C., Nowitz, A. \& Bogdanis, G., 2004. Skeletal muscle glycogen concentration and metabolic. Journal of Sports Sciences, Volume 22, p. 1065 - 1071.

Deswandi, 2012. Perbedaan Adaptasi Fisiologi Bagi Atlit Olahraga Anaerobik Dengan Aerobik Pada Kapasitas Vital Paru, UNP: FIK.

Effendi, H., 2017. Mengatasi Kecemasan Pada Atlet Sebelum Pertandingan Melalui Pendekatan Kognitif. Jurnal Menssana, 2(1), pp. 37-44.

Guyton, A. \& Hall, J. E., 2014. Buku Ajar Fisiologi Kedokteran. 12 ed. Jakarta: EGC.

Hairy, J., 2003. Daya Tahan Aerobik. Jakarta, Direktorat jenderal Olahraga.

Holway, F. E. \& Spriet, L. L., 2011. Sportspecific nutrition: Practical strategies for team. Journal of Sports Sciences, 29(S1), pp. 115125.

Linder, M. C. \& Parakkasi, A., 1992. Biokimia Nutrisi dan Metabolisme 
dengan Pemakaian Secara Klinis. Jakarta: UI-Pers.

Nugroho, S., 2013. Olahraga Aerobik sebagai Pencegahan dan Pengobatan Tekanan Darah Tinggi. Medikora, 10(1).

Pate, et al., 1993. Dasar-Dasar Ilmiah Kepelatihan.. Semarang: IKIP Semarang Press.

Primana, D. A., 2002. Kebutuhan Gizi Pemain sepakbola. Bogor, s.n.

Rismayanthi, C., 2015. Sistem Energi Dan Kebutuhan Zat Gizi Yang Diperlukan Untuk Peningkatan Prestasi Atlet. Jurnal Olahraga Prestasi, 11(1).

Sandi, I. N., 2019. Sumber Dan Metabolisme Energi Dalam Olahraga. Jurnal Pendidikan Kesehatan Rekreasi , 5(2), pp. 6473.

Sherman, W. et al., 1989. Effects of $4 \mathrm{~h}$ preexercise carbohydrate feedings on cycling performance. Medicine and Science in Sports and Exercise, Volume 21, p. 598 - 604.

Sherwood, L., 2018. Fisiologi Manusia dari Sel ke Sistem. 9 ed. Jakarta: EGC.

Subakti, S., 2010. Asupan Bahan Makanan dan Gizi Bagi Atlet Renang. Jurnal Ilmu Keolahragaan, 8(2), pp. 108122.

Sucipto, 2012. Sistem Energi, s.1.: UPI.

Syafrizar \& Welis, W., 2009. Gizi Olahraga. 1 ed. Padang: Wineka Media.

Wee, S., Williams, C., Tsintzas, K. \& Boobis, L., 2005. Ingestion of a high-glycemic index meal increases muscle. Journal of Applied
Physiology, Volume 99, p. 707 714.

William, J. H., 2008. TOURNAMENT NUTRITION: Strategies for Peak Performance, s.l.: The Science Of Soccer.

Williams, C. \& Serratosa, L., 2006. Nutrition on match day. Journal of Sports Sciences, 24(7), pp. 687-697.

Wolinsky, I. \& Hickson Jr, J. F., 1993. Nutrition in Exercise and Sport. 2 ed. London: CRC Press. 